\title{
Capitalism as an Ideology Criticized through Allegory in Ryūnosuke Akutagawa's Kappa
}

\author{
Rosa Vania Setiowati \& Elisa Dwi Wardani \\ elisa@usd.ac.id \\ Department of English Letters, Universitas Sanata Dharma
}

\begin{abstract}
Ryunosuke Akutagawa"s novel entitled Kappa (1926) is believed to be the allegory of Japanesetructure of politics and the economy in the $20^{\text {th }}$ century Japan. Yet, none of the study focused on describing the function of this allegorical Kappaland and its society to criticize the system of capitalism in Japan. Thus, the writer finds it important to scrutinize how the author of the story employs the allegory, as a rhetorical device of literary works, to criticize the reign of the dominant class in Japanese systems of politics and economy.

Focusing on the allegorical characters, setting, and significant events, this study seek for, the evidence that Kappa is the representation of Japanese society. Some events are created to signify the real condition of Japan in the early of 20th century, after the Meiji Restoration. The effect of industrial revolution brings several questions, including the role of the State and its apparatuses, to be problematized in this study. In addition, Akutagawa points out some of the lacks and shortcomings of humans through the allegorical characters and events in Kappaland. The settings are employed to show the life-likeness of Kappa and humans and support the wholeness of allegory. Analysis on parallelism of Kappaland and Japan is deemed important to reveal the criticism Akutagawa raises through the characters and the significant events. The setting of the story is pretty similar to what Japan was experienced, for instance the massive industrial production linked to the capitalist mode of production, the accumulation of power and wealth to the small amount of the dominant class. It is observed that Kappa is a disgusting and deformed mirror Akutagawa gives to humans to reflect their life.
\end{abstract}

Keywords: capitalism, ideology, Akutagawa

\section{Introduction}

The idea of capitalism grew in Japan during the Meiji period (1868-1912), as the island empire emerged from over two centuries of feudal isolation. Japan realized that the Western countries were far more advanced in the economic and political matter. Then, to be advanced, they had to imitate the way Western countries run their economic affair. It then marked the rise of industrialization in Japan. Many businesses were developed; the chance to export goods to outside countries was widely open.
During the time, the mode of production of Japanese society altered from the feudal to the capitalist mode of production. It was when the production of goods and materials no longer took place in the house of individuals as a home industry. Rather, the production was held in factories which were owned by individuals or groups who paid the people to work in their company. This is what Marx, describes as the system of production in which a number of craftsmen were assembled under one roof. This system had characterized the European industry from about the middle of the sixteenth century to the last third of the eighteenth century (Ike, 1949:186). 
A well-known economic historian Takao Tsuchiya in Ike argued that Japanese industry had not been sufficiently advanced to develop into a modern capitalist industry on its own power. He asserted that the shift to modern factory industry had been achieved through the intervention of the Meiji government (1949:186). Many critics argue that the Japanese model of the economy is a state-sponsored capitalism, which means the economic system under the government investment to certain sectors of the economy to stimulate the industries in the private sector. "Industrialization in Japan produced a new economic elite who, as the leaders of modern business enterprise, were responsible for mobilizing the nation"s resources and creating economic institutions suitable to an industrial society" (Marshall, 1967:2).

Japan was the only non-Western society to successfully industrialize in the 19th century (Fulcher, 2004:73). However, Japan manages a distinctive capitalism in which the state played a directive role and corporate concentration took the form of industry groups that expanded across the economy. The weakness of labor organization was another distinctive feature Japan had. Because of the growth of the machine, and above mentioned distinctive features were further developed during the postwar period, Japan maintained to grab the position as the second largest economy in the world (Fulcher, 2004:74).

However, even if the state invested in the new or specific industries to stimulate the growth, on the practical level, the greater amount of capital remains privately owned. The capital, including the land and economic production, is not shared fairly for the greater good of every level of society. This case highlights the similar characteristic that is found under any kind of capitalism, the one that is held in the Western countries or in the East. The characteristic is, the working class is treated like commodity since they sell their labor power to the owner of land and capital. They are prone to suffer unemployment when their labor power brings no profit in the transaction.
Within the Marxism discourse, the relation between the bourgeoisie, the dominant class who control and own the means of production, and the proletariat, the subordinate class who do not own and control the means of production, became the key concept to understand what is unfair under the capitalist system and industrial society. The capitalist class accumulates more and more wealth by running companies and taking advantage of the labour power from the working class, while the proletariat is forced by a socio-economic compulsion to sell its labour-power to the capitalist owners of the means of production. Contradictory character of capitalism manifests itself in the accumulation of wealth "at one pole", and of poverty and misery at the other (Giddens, 1971:58).

Such change in social, political, and economical condition is often recorded by some authors in their literary works as the response of that major alteration. At the end of Taisho period, Ryunosuke Akutagawa finished writing Kappa, a novel containing 17 short chapters. Portraying the life of human from Japan who set foot in the land of Kappas, in which their existence is still disputable. Some similarities of Japanese society and events can be seen in the life of Kappas. However the different mentality of Kappas as a gap and the critics of Kappa upon the human condition, especially the political and economic condition, frequently emerge in the story.

It was primarily put in by Taiji as "a distillation of the author"s feeling of revulsion from the whole of human life" (Healey in Akutagawa, 2009:40). The novel was firstly published in Japan in March 1927. Kappa, according to Japanese folklore, is a scaly creature about the size of a small child, with a face like a tiger"s and a sharply pointed beak (Healey in Akutagawa, 2009:35).

Concerning the relation between literary works and politics Akutagawa points out that literature is not unrelated to politics; it is in fact one of the major characteristics of literature (Yu, 1972:50). His view is similar to what Lukàcs in Eagleton believes that "all great art is socially progressive in the sense 
that, whatever the author"s conscious political allegiance, it realizes the vital „world-historical" forces of an epoch which make for change and growth, revealing their unfolding potential in its fullest complexity" (2002:27).

To satirize the life of Japanese society during the rise of capitalism, Akutagawa used the symbol of kappa to portray how this ideology brings a great amount of privilege and power to the owner of the mode of production. Yu (1972:50) in his critical study of Akutagawa stated, "steeped in the tradition of Swift, Voltaire, France, and Shaw, Akutagawa also had an ability to adapt even fairy tales to his satirical purposes."

In his work, Akutagawa chose the role of capitalists, philosopher, judge, and several kinds of kappas to represent the human world in an exaggerating way. Some values in the human world and in the Kappaland are intentionally collided to make the readers think that there is something wrong with the system working in the society and thus a moral reform is necessary to be pursued. Yu asserted that with Akutagawa"s sense of wit and irony and his angle of vision, he was an accomplished satirist (1972:86).

Under the light of Marxist literary criticism, this study concerns with the capitalist mode of production and the class oppression raised by Akutagawa in the novel, which is somewhat similar to the problem in the human world, specifically Japan as the home country of the main character and Akutagawa himself. This thesis focus on figuring out the parallelism used by Akutagawa and answering why he used the kappas as an allegory instead of projecting the problem with the human character.

After proving that the characters in Kappa are the allegory of Japanese society, the writer then analyzes how capitalism as an ideology works in both Kappaland and Japanese especially in 1920s. This study is necessary to be taken because the writers want to prove that how the practice of capitalism in Japanese society raised during the 1920s documented in a literary work. Two particular points are going to be closely examined. The first is how the society of Japan is revealed through the allegory in the novel, and the second is how is capitalism as an ideolgy criticized through the allegory.

\section{Allegory}

Allegory is a form of extended metaphor in which objects, persons, and actions in a narrative, either in prose or verse, are equated with meanings that lie outside the narrative itself (Holman, 1960:11). The outcome of allegory is representing one thing in the guise of another, which forms an abstraction of a concrete image. The characters in the allegory are usually personifications of abstract qualities, the action and the setting representative of the relationships among these abstractions. Holman makes it clear that through the characters, events and setting created by the author, allegory is intended to reveal the meaning beneath the story. Such meaning may be religious, moral, political, personal, or satiric (1960:11).

One might find difficulties in distinguishing allegory and symbol for these two literary devices suggest the other level of meaning. However, allegory differs from symbol in the sense that symbol is "an expression of experience perceived as selfsufficient, completely adequate in itself" (Cowan, 1981:110). While, it is suggested by Holman that "an allegory the objective referent evoked is without value until it is translated into the fixed meanings that it has in its own particular structure of ideas" (1960:436).

Literary allegory has been treated by turns as a genre, a mode, a technique, or a rhetorical device or trope, related to metaphor and sometimes defined as extended or continued metaphor. However, Boyd (1860: 86) argued that even if allegory is generally considered, as a continuation of metaphor, no continuation of metaphor ever becomes an allegory. He explains that there are several essential properties that distinguish allegory and metaphor. The essential features he points out is that allegory presents to immediate view of the secondary object only; metaphor always 
presents the primary also. Metaphor always imagines one thing to be another; allegory, never. Everything asserted in the allegory is applied to the secondary object; everything asserted in the metaphor is applied to the principal. In the metaphor there is but one meaning; in the allegory there are two, a literal and a figurative (1860: 86).

As a rhetorical device, which is a means intended to influence people, allegory is suggested as "a paradigmatic instance of rhetoric and rhetorical language, of the sign whose meaning cannot be fixed but is continually deferred, both calling for and resisting interpretation" (Copeland, 2010:10). Additionally, it is argued that allegory, as a sign of deferred or absent meaning, has occupied a critical position, as the tropes of tropes, by its very name ("other-speaking") announcing itself as the definitive mark of the contingency of language and its referential claims. In relation to this issue, de Man famously suggests that "all reading, all critical practice, is allegoresis, that is allegorical interpretation" (Copeland, 2010:10). Thus, to get the sense of the meaning beyond the story, the readers might apply allegorical reading, a reading with the interest in locating some hidden, another meaning under the surface of a story or any literary works.

To form an allegory, Boyd (1860: 86) proposes that "the mind must look out for a likeness that will correspond in a variety of circumstances, and form an independent whole". His argument might explain the essential feature allegory employs, which is the likeliness of the story with the situations in the world of the author and the reader. It explains that there is a correspondence between an independent whole story of an allegory with the variety of circumstances happen in the world of human. This feature does not appear when one tries to employ metaphor. Boyd argues to form a metaphor, what writers should do is a slight exertion of imagination, and it requires no study.

Another figure allegory has is that it should have a lively and interesting story as possible. Keeping the distinction between the figurative expression and the literal is essential. The distinction also functions to introduce nothing unsuitable to the nature, either the thing spoken of, or of the thing mentioned in an indirect way. In other word, the allegory should have its individuality and distinction with the reality of the author and the reader. Between the surface signifier and its hidden referent exists a bond of meaning that is not capricious, but rather essential (Fletcher, 1964:70). The true criterion for allegory Fletcher suggests:

The whole point of the allegory is that it does not need to be read exegetically it often has a literal level that makes good enough sense all by itself. But somehow this literal surface suggests a peculiar doubleness of intention, and while it can, as it were, get along without interpretation, it becomes much richer and more interesting if given interpretation. Even the most deliberate fables, if read naively or carelessly, may seem mere stories, but what counts in our discussion is a structure that lends itself to a secondary reading, or rather, one that becomes stronger when given a secondary meaning as well as a primary reading (1964:7).

An allegory becomes political if it covers a political event or situation by producing a subtle commentary on it using other symbols. The term political allegory can also be applied to the use of fictional characters as direct substitutions for real politicians. However, not all political allegory is intended. Using the objects, characters, figures or colors to represent an abstract idea or concepts, the author might use the allegory as a rhetorical device to criticize or satirize the political condition and the ruling government in their era. This is similar to the notion that allegory can function as "a means of making satire direct and immediate" Leyburn (1948: 329). Edgar Johnson in Leyburn suggests that there is always "the possibility of letting the author step aside from his allegorical structure and affords a detachment infinetely valuable to the satirist"(1948:329). 


\section{Theory of Ideology}

According to Marx ideology is the system of the ideas and representations which dominate the mind of a man or a social group. There are three major characteristics of ideology when understood through Marxist perspective. Thefirst character is that to be of any value, ideology must reflect the real and practical social conditions within a society. The second, the social conditions in a society that serve as the basis for an ideological framework will reflect the productive forces in that society. The last is that an ideology that reflects productive forces will serve to promote the interest of the dominant social group or class within the relations of production (Spisso, 2006: 83-84).

Ideology, for Althusser, is not a mere concept. It has a material existence, because "an ideology always exists in an apparatus, and its practice, or practices" (1971:112). His concept of Ideological State Apparatus, which is the apparatus of the state which contributes to the reproduction of the relation of production, i.e. of capitalist relations of exploitation, was the realization of ideology (the unity of these different regional ideologies religious, ethical, legal, political, aesthetic - being assured by their subjection to the ruling ideology).

He presents two theses, in order to approach his central thesis on the structure and functioning of ideology. The first concerns the object which is "represented" in the imaginary form of ideology, the second concerns the materiality of ideology. His first thesis is that "ideology represents the imaginary relationship of individuals to their real condition of existence". He argues that so many world outlooks are there in our life, for instance, what we commonly call religious ideology, ethical ideology or political ideology. These world outlooks, he argues, are largely imaginary, i.e. do not „correspond to reality".

In other words, Althusser said that ideology constitute an illusion. It does make allusion to reality, and that they need only be "interpreted" to discover the reality of the world behind their imaginary representation of that world. What is reflected in the imaginary representation of the world found in an ideology is the conditions of existence of men, i.e. their real world.

Althusser thesis supposes that "it is not their real conditions of existence, their real world, that "men" represent to themselves in ideology, but above all it is their relation to those conditions of existence which is represented to them there" (1971:164). What he means by the quotation above is that ideology is not a distorted image of reality, but rather an imaginary distortion of people"s relation to reality. He further argues that what is represented in ideology is therefore not the system of the real relations which govern the existence of individuals, but the imaginary relation of those individuals to the real relations in which they live.

\section{Theory on State Apparatus}

\section{Repressive State Apparatus}

Marxists classics in its theory of State claimed that the state is the repressive State apparatus. Meaning that the State always uses political and military force to control a group of people and restrict their freedom. In his attempt to explain how ideology works, French philosopher, Louis Althusser (1971) notes that this theory of States suggests several theses.

First, state power and state apparatus must be distinguished. Second, the objective of the class struggle concerns State power, and in consequence the use of the State Apparatus by the classes (or alliance of classes or of fractions of classes) holding State power as a function of their class objectives; fourth, the proletariat must seize State power in order to destroy the existing bourgeois State apparatus and, in a first phase, replace it with a quite different, proletarian, State apparatus, then in the later phases set in motion a radical process, that of the destruction of the State (the end of State power, the end of every State apparatus).

Althusser expands the theory of states in which he believes not only the state apparatus and the state power must be 
distinguished, the state apparatus also has two different groups that must be set apart. In his essay on Ideology, he proposes the idea of Repressive State Apparatus (RSA) and Ideological State Apparatus (ISA). The definition of Repressive State Apparatus is generally similar to what Marxist theorists propose before him, which is any apparatuses controlling society"sbehaviour and freedom using the means of repression.

He claims that all the state apparatuses function both by repression and by ideology, with the difference that the Repressive State Apparatus functions massively and predominantly by repression, whereas the Ideological State Apparatuses function massively and predominantly by ideology. The example suggests that "the Army and the Police also function of ideology both to ensure their own cohesion and reproduction, and in the "values" they propound externally" (Althusser, 1971:145)

This ideological function of RSA works when the academy of Police or Army recruits new members. To alter the civilians of nonapparatuses to become a repressive apparatus they should not be treated by force or repression. Some ideological values should be introduced and internalized as the means of reproduction of the corps. In addition, by functioning through ideology the Repressive State Apparatuses are able to get society"s supports for their repressive action.

Insofar as it is a repressive apparatus, the role of Repressive State Apparatus consists essentially in securing by force (physical or otherwise) the political conditions of the reproduction of relations of production which are in last resort relations of exploitation. Not only does the State Apparatus contribute generously to its own reproduction (the capitalist State contains political dynasties, military dynasties, etc.), but also, above all, the State apparatus scores by repression (from the most brutal physical force, via mere administrative commands and interdictions, to open and tacit censorship) the political conditions for the action of the Ideological State Apparatuses.
Repressive State Apparatus also provides „shield" for the Ideological State Apparatus to secure the reproduction specifically of the relations of production. It is here that the role of the ruling ideology is heavily concentrated, the ideology of the ruling class, which holds State power.

\section{Ideological State Apparatus}

According to Althusser, ideology has the material condition which is the materialization of ideas into a practice. Althusser suggests that ideology existing in a material ideological apparatus, prescribing material practices governed by a material ritual, which practices governed by a material ritual, which practices exist in the material actions of a subject acting in all consciousness according to his belief. Its material condition is ensured by the existence of Ideological State Apparatuses (ISA).

A relatively large number of ideological State apparatuses were listed by Althusser (1971:143). They are the educational apparatus, the religious apparatus, the family apparatus, the political apparatus, the tradeunion apparatus, the communication apparatus, and the "cultural" apparatus. He proposes that ISA should not be confused with the RSA by saying that "there is one Repressive State Apparatus, there is a plurality of Ideological State Apparatus" (1971:144).

The unified Repressive State Apparatus belongs entirely to the public domain, which suggests that RSA is under the control of one unit, the State. On the other hand, Ideological State Apparatuses are part of the private domain, namely churches, political parties, trade union, families, some schools, most newspapers, and cultural ventures.

To tackle the arguments which question why above listed agents are regarded as the agent of the State despite of their attachment to the private institution, Althusser (1971:144) argues that "what matters is how they function. Private institutions can perfectly well "function" as Ideological State Apparatuses". When an agent in the private domain functions massively and 
predominantly by the ideology of the ruling class, it serves the function as the Ideological State Apparatus.

The ISAs work as the agent to formulate and materialize the teaching of ideology in a realization of action. This realization in a small part of the apparatus is, for instance the school day, a funeral, a minor match at a sports club or a political party meeting. However, no Ideological State Apparatus is purely ideological, as Althusser proposes:

Ideological State Apparatus functions massively and predominantly by ideology, but they also function secondarily by repression, even if ultimately, but only ultimately, this is very attenuated and concealed, even symbolic. Thus, there is no such thing as a purely ideological apparatus (1971: 145)

Some Ideological State Apparatus might work as the agent of punishment, expulsion and selection. Schools and Churces are the example of ISA which function is to discipline their students and followers.

\section{Marxist Theory on Capitalism}

The concept of capitalism denotes a mode of production in which capital in its various forms is the principal means of production. Capital, in the forms of credit or money, is important to buy the labour power and materials of production such as raw materials and machinery. The prominent feature of capitalism as a mode of production is "the private ownership of capital in the hand of a class - the capitalist class as an exclusion of the mass of population" (Bottomore, 1991:71- 72). The investment on capital in the expectation of large profit differentiates the capitalist mode of production from the previous mode of production.

According to Marx, the key to capitalism - or any other mode of production, for that matter-is the organization of production. Under capitalism, labour power becomes a commodity, bought and sold on the market just like any other commodities, and for many people the sale of that labour power is their only source of livelihood. In contrast to feudalism, capitalism is characterized not by the coercive power or landowners over peasants, but by the sale of labour power on the basis of a wage contract (Howell, 1995:4).

In other words, capitalism as mode of production is a market where labor powerthe working class" only means of survival-is bought and sold. The control of the production (labour) process is on the hand of the capitalist or his managerial agent, which covers the power over hiring and firing workers. In addition, the implication also covers the choice of techniques, the output, the work environment and the arrangement for selling the output (Bottomore, 1991:72).

Capitalism developed by destroying the feudal mode of production and replacing it with one based on absolute private property and the market, which made possible far higher levels of productivity (commodity production). In the feudal mode of production, the ownership of the property remains in the hand of the lord, while the serfs are forced to work in the land owned by the landlords. Meanwhile, in the capitalist mode of production, workers who had owned their looms or tools eventually had nothing to sell but their labour. The inherent contradiction is expressed in the conflict of interest between capitalist and worker. The central to the nature of the capitalist mode of production is the private accumulation of capital as the foundation of factory working. The capitalists want to pay the working class" labour power as low as possible to generate more profit and accumulate more wealth. In the other hand, the working class struggles to get paid higher than they should be.

Capitalist mode of production began to emerge when individuals who had accumulated the first capital created workshop, that is enterprises where workers labored side by side for a wage and on their employer"s account. These workers had formerly been independent masters of the product of their labor. Yet, because they are deprived of the mode of production, these workers control nothing but their labour power: 
The working class consists of those who own nothing but their own labour power. Because workers have no other access to the means of production and have to sell something in order to live they are forced to sell their labour power and cannot make use of its value-creating property themselves. So workers are exploited not by unequal exchange in the labour market, for they sell their labour power at its value, but through class position of having to enter the capitalist production process wherein exploitation actually occurs (Bottomore, 1991:529).

The process of buying and selling labour power in the capitalist mode of production is exploiting in the sense that workers must bargain in the condition of fear to face starvation or losing a home whereas the capitalist bargains under no pressure to employ the workers. Furthermore, as the central exploitation, the owner of the means of production extracts the surplus value, which is the value created by the labour over and above the value of his labor power which is appropriated without payment by the capitalist.

Under the capitalist mode of production, class was a uniquely prominent featureclass itself is a product of the bourgeoisie. Marx in Bottomore argues that

in so far as millions of families live under economic conditions of existence that separate their mode of life, their interests, and their culture from those of the other classes, and put them in hostile opposition to the latter, they form a class (1991).

The invention of automatic machinery made it possible to replace the craft workers with the less skilled and cheaper labour. By hiring the less skilled and cheaper labour, the factory is able to minimize the wage cost apart from holding wage rates down (Fulcher, 2004:6). Keeping the wage cost of workers down is the form of exploitation generates by the capitalists. Additionally, capitalist mode of production fosters exploitation by disciplining the workers. Moreover, capitalists get the profit by exploiting the surplus labor time of workers. What is called by Marxists theorist as surplus value that is well explained by Bottomore:

Surplus value is the difference between the two, the value produced by the worker which is appropriated by the capitalist without equivalent given in exchange (1991:529)

\section{Review of the Tokugawa - Meiji Periods}

A well-known notion pronounces that "where feudalism ends, the capitalist regime commences". This historical background shows the transformation from feudalism to capitalism from the Tokugawa period (16031867) until the Meiji period (1868-1912) in Japan.

The essential character of the new Meiji state was not substantially different from that of the Tokugawa regime and farmers were exploited as severely as they had been hitherto. From this point of view, the Meiji state can be considered as a semi feudal state which is a natural continuation of the Tokugawa regime. However, the type of economy established after the Meiji Revolution was very far from that type of capitalism in which England started to advance.

The central and various local governments operated productive and commercial business either directly (i.e. by using their own samurai for management or work force) or indirectly (i.e. by leaving the business in the hands of their chartered merchants) (Morishima, 1986:18).

Two types of merchants emerged in Japan during Tokugawa regime. The first is in castle towns and the latter in villages. Receiving a number of privileges from the clan government, the former were allowed to form guilds (kabu-nakama) which gave them a monopoly of the right to trade in town, whereas in many respects, the town merchants dominated the village merchants. They were capitalists who had a more advantageous position that the merchants in the castle towns, because they were able to 
control the industries to earn for themselves the profits from production.

New Western style workshops were established toward the end of the Tokugawa era. As the remnant of the Tokugawa era, the system of clan still be retained. Clans were responsible for districts and areas. For instance, Saga clan, which was asked by the Tokugawa to be responsible for Nagasaki were advantageous compared with other clans of easier access to Western technology. The Satsuma clan started a wool-spinning workshop in 1819 developed their business to produce cannons, guns, medicines and glass in 1846.

After the revolution known as Meiji Revolution, the central government abolished the clans and the caste system within a few years. The government took over many of the factories and other organizations such as school which had been owned by clans. In the early days of the Meiji era, the state owned factories played an important role. The modern factory equipped with completely Western style machines of the Satsuma clan, which was taken over by the new government played an important role in promoting the new Western method of production (Morishima, 1986:21).

In the early $20^{\text {th }}$ century, Japan was acquainted with the sub-division of manufacturing industry, which is categorized into five groups: (1) food and drink, (2) paper, ceramics and chemicals, (3) machinery and tools, (4) dyeing and weaving, and (5) miscellaneous. Each of them can be subdivided into the small, medium-sized and large factory sectors, according to the number of workers of the factory. The small factory employed between 5 and 49 labour, while the medium- sized employed between 50 and 499 labour. The large factory employed more than 500 labour (Morishima, 1986:24).

In Japan, the transformation to capitalism was very much evolutionary, not revolutionary, the political upheaval of the Restoration period notwithstanding. Capitalist production had already begun to emerge in the early nineteenth century Japan, and the Tokugawa state had already begun to formulate a response-albeit an inadequate one-before it fell in 1868. The succeeding Meiji regime completed its accomodation to capitalism over the remainder of the nineteenth century, with the result that scattered instances of capitalist productive relations gave way to a capitalist mode of production (Howell, 1995:5).

\section{Parallelism between Kappanese and Japanese Society}

\section{Allegory of Setting}

Whenever a guest pays a visit for the main character, Inmate No.23, in the mental hospital, he will tell his story of travelling to Kappaland. It is a place where he lived in several months with the mythological creature, Kappa. Kappaland is the particular physical location in which the story takes place. It thus serves the function as the setting of the story.

Inmate No. 23 fell into the Kappaland because of his curiosity of the mythological creature. One fine summer, he encountered a Kappa when he was hiking to the Mount Hodaka. To catch the Kappa he encountered in Azuza Valley, he ran into the shadow of the Kappa and immediately snatched it. Eventually, it led him slipping into a hole to Kappaland.

Out of the main character's surprise, the Kappas live in a very different kind of life which is commonly portrayed in several mythological books. Some books and folklore records in the world of the narrator describe Kappa as a mythological creature who live in the river or the lake. However, Inmate No. 23 found that they are not living that way.

One might think that Kappa lives in a wild area, just as how the animals live. Supposing that they are mythological creature, the storytellers in the book of mythology would not assume that they have a civilized structure of society. However, what Kappaland is drawn by Inmate No. 23 is different from theirs. 
In Kappaland, Kappas live as a well organized society with a developed culture and way of live. Their civilized society is progressing under the rule of government. Kappas own a developed city, housing, even use cars as the mode of transportation. In addition, they live under the State with the parliamentary system, which employs the police and the army as the state apparatuses.

Akutagawa, through Inmate No. 23 describes the setting of Kappaland as follows: "then we went for several hundred yards along a street which, for all I could see, looked just like Ginza, the main street in Tokyo" (Akutagawa, 2009:52).

After some time loosing his consciousness, Inmate No. 23 was awakened in the Kappaland. When Inmate No.23 gained his consciousness, he was aware that he was carried through the throng of Kappas passing a street which resembles Ginza.

It is not too difficult to notice that the setting of Kappaland resembles Japan. Inmate No.23 himself as a human who all of the time lives in Japan notices the similarity between Kappaland and Japan. He says that "it had a similar line of beech trees on each side and a steady stream of cars filled the road between them. In the shade cast by these trees, there were rows of shops; these dealt in everything you could think of and each sported its sunshade" (Akutagawa, 2009:52).

The representation of Japan also appears in the concert hall of Kappaland. Inmate No. 23 once came to a concert with Tok, the Kappa poet. He thinks that "of course, there was hardly any difference between the layout of Kappa concert halls and ours in Japan. Theirs, too, had rows of gradually banked seats, and all the other things I know so well" (Akutagawa, 2009:75).

These similarities might be one of the reasons why Inmate No. 23 was able to adapt and live in Kappaland for several months. In other words, Kappaland can be regarded as a miniature of cultured life of Japan. Ranging from the streets that resembles Ginza, Tokyo; the house arrangement, the concert hall, and the cultural practice of the inhabitants who love to enjoy and express themselves through art performance. All of this parallelism indicates that the story of Kappa is a correspondence of the Japanese people. There is something that Akutagawa wants to say through such setting. If not, he would rather create a setting such as the life of Kappas on the river or lakes, similar to what the author of mythological books describes about Kappa's life and civilization.

\section{Allegory of Characters: Gael as the Representation of Japanese Capitalist}

Gael is the director of a glass corporation in Kappaland, which is along the story is called capitalist Kappa. Among the other Kappa represented in this story, he is a prominent character who is very often engaged in the discussion with Inmate No. 23 and several Kappas, including Chak, the doctor Kappa, and Pep, the judge. Even if Gael is in the form of Kappa-not a human-he is considered as a character because he represents particular moral, intellectual, and emotional qualities of what a person says and does.

Gael frequently invites his fellow friends to eat in his luxurious house where the whole room, including the tables and chairs, is in Secessionist style, with a thin gold rim on white ground. Inmate No. 23 suggests that "from time to time, I used to go out to Gael's house for dinner, in the company of either Judge Pep or DrChak" (Akutagawa, 2009: 81).

Inviting the reader to get a closer look at the physical features of Gael, Inmate No. 23 describes Gael. To some extend, Inmate No.23 considers Gael's appearance disgusting. Inmate No. 23 utters that no one in Kappaland is as disgusting as Gael. He reveals that "not even in this land of fat paunches was there one that sagged and bellied out quite as disgustingly as Gael's" (Akutagawa, 2009: 81). One should not read this description literally, for Kappa and human's physical appearance are essentially different. Accordingly, this judgement will make a sense when it is read metaphorically. Gael's 'sagged and bellied out fat paunches' is used by the author to criticize the nature of a capitalist, who, at some point is disgusting as 
he accumulates the resources and capital to enrich self. The description associated human's greed.

From time to time, by the accompany of Gael Inmate No. 23, went to Gael's clubwhere Kappas spend their time listening to the music and dance with other visitors-and spent an extremely delightful evening with him there. This is another indication that Gael lives in an extravagant life. Not all Kappas are lucky or rich enough to own a club. Compared to the fisher Kappa, Bag, Gael lives a very luxurious life. Bag, as described by Inmate No. 23 is living in a cottage. Even if the narrator does not give any further explanation about the life of $\mathrm{Bag}$, the reader may draw a conclusion that the life of Gael and the fisher Kappa are in any way different.

As the director of a huge glass corporation he owns the means of production, such as the land, the factory, and the machines, which serve as the means to ensure the production. The ownership of the means of production distinguishes him from other Kappas who do not possess them. The Marxist view suggests that it is the ownership of the means of production that determine ones' position in the relation of production.

Also, as a capitalist, Gael is not compelled to sell his labour-power in order to survive. Instead, he buys the labour-power to work for him in order to generate profit. In short, his amount of daily life does not belong to someone who buys his labour-power. In one way or another, Gael is connected with the other capitalists, as it is suggested by Inmate No. 23. He asserts that "Gael would often give me introductions for visits to a great variety of factories or plants which were connected in some way either with him or with one of his many friends" (Akutagawa, 2009: 81).

Commodities in which Gael's factory produces are significant to the development of allegory. Glass and coal are the products made by Japanese workers during the Meiji Restoration (1868-1912). Thus, Gael's identity as the owner of glass corporation and the supplier of coal during the war is parallel with the condition of Japan at the beginning of 20th century.

\section{Allegory of Events}

\section{The Use of Highly Mechanized Tools in Factory}

In Kappaland, the highly mechanized tools are used in the factory. The director of a glass corporation, Gael, once introduces Inmates No.23 to one of the factories in Kappaland, the book manufacturing, which Inmate No.23 found fascinating. Inmate No.23 was shown around the factory by a young Kappa engineer. They stopped to look at an enormous contraption driven by hidroelectric power then Inmate No. 23 said to himself, "once more, I found myself astonished by the advance state of mechanization in the industries of Kappaland" (Akutagawa, 2009:82).

The volume of production in the book manufacturing factory reached the region of seven million. This was due to the characteristics of the machines they used. "The ingredients are fed into the machine and, in barely five seconds, they are ejected as octavos, duodecimos, royal octavos and so on" (Akutagawa, 2009:82). Surely, all of the fascinating gesture made by the machine and the rate of production in only several seconds cannot be done by human or Kappas in general.

Meiji Restoration has transformed Japan's economy. Industrial production rose five times and exports soared, and Japan had become a creditor nation by 1920 :

Industrial production was almost doubled during the period between 1914 and 1919. The average profit rate for industry, which in the first half of 1914 was 40.8 per cent, rose during the three-year period 1917-1919 to 55,2 per cent. During this time, in areas like shipping, ship-building, and mining, the profit rate even rose as high as 160 to 200 per cent (Kato, 1998: 32)

Extending their interests in all kinds of industrial activity, the zaibatsu (cohesive family-controlled groups of monopolistic companies in key economic areas), like Mitsui and Mitsubishi, grew in power. 
The portrayal of mechanization in Kappaland industries is in line with the Japan government agenda to promote industrialization and modernization. "The process of Japan's emergence as a modern state necessarily involved an institutional transition from feudalism to capitalism" Shigeto (2000: 283). Japan adapted imported capital-intensive technology to more effectively utilize labor. Before Japan imported a single cotton-spinning machine or built a single mile of railroad, the state completed a reverbatory furnace in 1852 , imported a lathe- machine in 1856, and constructed a shipyard for steam-operated warships in 1863 (Shigeto, 2000: 284).

The use of highly mechanized tools is the sign of modernity and efficiency in making goods. More and more tools are produced to support that mode of production. As in the depiction of industrial production, Akutagawa's Kappa suggests that “...in an average month Kappaland sees the invention of as many as seven or eight hundred new devices of this kind" (Akutagawa, 2009:83). Akutagawa portrayed the condition when human realizes that to maximize the quantity of production as well as their profit, they should rely on mechanization and thus produce more powerful and efficient production devices.

Japan was regarded by Ike (1949) as "the most successful (country in Asia) in adopting modern methods of industrial production". The individuals who had acquired their wealth through commercial operations and the practice of lending money at the very high rates of interest became industrial capitalist. This is one of the origin of Japanese industrialization. In the early 20th century, Japan was acquainted with the sub-division of manufacturing industry, which is categorized into five groups: (1) food and drink, (2) paper, ceramics and chemicals, (3) machinery and tools, (4) dyeing and weaving, and (5) miscellaneous (Morishima, 1986: 24).

\section{War with Neighboring Country}

Kappaland was at some time after a war when inmate No.23 stayed there. The war waged between Kappa and Otters. Otters are neighbor to kappa since they are living near Kappaland. Inmate No. 23 knows the fact through Gael, the capitalist. Gael explains that Kappa was engaged in a war with Otter, the constant potential enemy. "Yes, I'm afraid that's just about it.... But something like that war incident of seven years ago, for instance..." (Akutagawa, 2009:89). The conversation below between Inmate No.23 and Gael, the capitalist, shows that Kappanese happened to experience a war and they managed to win the war:

"Who won the war, then"

"We did, of course! 369,500 Kappas fell nobly in the campaign. But compared with the losses they enemy suffered this was pretty negligible. Practically every piece of fur in this country is Otter" (Akutagawa, 2009:91)

This similar condition happened in Japan during the Taisho period, that they were engaged in war with several countries.

Kappa war with Otters is parallel with the fact that Japan had been in the Sino-Japan War in in 1894-1895 and the Russo-Japan War in 1904-1905. Following the lack possesion and inadequate natural resources, Japan set a war with her neighboring country, China. The raw materials were needed to supply growing manufacturing industries. This fact motivated them to invade China, causing huge loss in the other side. Growing political rivalry to dominate Korea and Manchuria trigger Japan and Russia to set the war.

Through the war with China in 18941895 and with Russia in 1904-1905, Japan experienced a rapid expansion of capitalist industry and the growth of an impoverished proletariat, whose wages were held back by the still proportionately massive peasantry and rural unemployed (Bottomore, 1991: 365).

\section{Censorship and Ban on Cultural Products}

The vivid image of the State showed up in the form of policemen. During a performance of Krabach, the Kappa 
composer, a group of kappa policemen halt the music to be played. It was started with a policeman who sit behind Inmate No. 23 who "lolled back sumptuously in his seat...even more loudly than on the first occasion" (Akutagawa, 2009: 77)

'Stop the performance!' And then... An then, all hell broke loose. Shouts and screams echoed and re-echoed across the body of the hall.

'Down with police tyranny!' 'Play on Krabach! Play on!' 'You bloody fool!'

'You filthy bastard!'

'Get out! Get out of here!'

'Dont't let yourself be browbeaten, Krabach. Play on!' (Akutagawa, 2009: 77)

In the middle of the performance the Kappa policeman shouted to Krabach the composer to stop the performance in an intimidating voice. However, the composer was not at any point willing to stop his performance. Krabach did not want to stop. Instead, he kept playing in the midst of chaos.

The Kappa police as an apparatus of the State, is employed to set the standard in the music. The performance of music with the unclear message will be prohibited and banned. To the extend whenever the live performance of the unaccepted music is held, the police should come and prohibit the performance to be continued.

When Inmate No. 23 asked about what is going on, Mag answers him with: "this you mean? Oh, it's nothing to fuss about: it's always happening here! The essence of painting and writing...." (Akutagawa, 2009: 78). Mag explains to Inmate No. 23 that such action is happening all the time. The State is not only prohibit the music but also the painting and writing. Those cultural products must have clear meaning, so that the readers, or listeners and everyone know the writer or composer's intention and expression behind the products they make. Mag explains that

The essence of painting and writing is that it should be absolutely obvious to anyone and everyone what it is that the artist and the writer aim to give expression to. As a result, this country we have never practiced anything on the lines of a prohibition on sale or exhibition Akutagawa (2009: 78)

The cencorship on cultural products also happened in Japan. Since the raise of naturalism between 1906-1902, supression became more intense during the years of growing militarism. Not to mention during the war years, Japan's twentieth-century literature, the State and the conservatives saw the literature with individualism, naturalism, modernism, socialism and libertarianism theme as a fall on the moral and behaviour. Thus, it should be prohibited.

\section{Capitalism as an Ideology Criticized through Allegory}

\section{How Capitalism Works in Kappaland}

According to Althusser, ideology is embodied in material practices. He suggests that "an ideology always exists in an apparatus, and its practice, or practices. This existence is material" (1971: 166). He admits that ideology does not correspond to reality. Instead, it creates an illusion. In other words, ideology make allusion to reality. To unfold the reality of the world behind the imaginary representation of that world, ideoloy should be interpreted.

In the story narrated by Inmate No. 23, the author shows how the capitalist mode of production is promoted in Kappaland. The capitalist mode of production is the system of production within a capitalist society, where the ownership of the means of production, such as the raw materials, the factory, the machines and tools are in the hand of the private entity. The means of production are usually held by the owner of capital, while the ones who do not own capital works as wagelaborers. Here are some practices of capitalism in Kappaland as the material existence of capitalist ideology.

First, the private ownership of mode of production. Most of the factories in Kappaland are owned by private entities. One of the examples is the glass corporation that is owned by Gael. As a managing director of the huge glass corporation he has no much 
work to do. He does not have the responsibility to engage in the simple manual labour, but specialized into a privilege work. By employing the working class, he can live a prosperous life: ...when he lounged in his easy chair at home, surrounded by his wife (she was, by the way, the image of a litchi) and by his cucumber-shaped children, Gael was the picture of bliss (Akutagawa, 2009: 81).

Second, the mass production and the growing number of machines. During his visit to Kappaland, Inmate No. 23 finds that the mode of production in one of the factories is supported by the use of machines. In his visit to a book factory, he watched all the "different sized books cascading from the machine like a torrent..." (Akutagawa, 2009: 82). The production of the books is no longer supported by the kappa workers. The same sort things occur also in the production of both art and music. This is the indication that the capitalism has grown into a more sophisticated form.

Third, the government law to slaughter the unemployed Kappa. The capitalist ideology is not only working in the mode of production, but also influence the law that the State enact. In the midst of the massive unemployment, the State of Kappaland is not enacting a law to prevent the working class to be laid off. The State does not provide a safety net for the unemployed kappas so that they will not suffer much from the condition. Instead, the State allows the unemployed kappas to be slaughtered. It is revealed when Pep, the judge kappa explain to Inmate No. 23. Pep says "you see, we have a statute covering the butchery of the worker" (Akutagawa, 2009: 84).

From the three examples above, it can be concluded that the factories in Kappaland apply the capitalist mode of production. Not only it is seen from the mode of production, but also the law enacted by the State covering the subordination of the working class. The system of capitalism has been working in Kappaland through the relation of production, i.e. the dominant class subjects the working class. Moreover, it is supported by the government through its law. Thus, it shows that the ideology of capitalism, as the system of ideas which dominate the mind of a man or social group, is working in the Kappaland.

\section{The Role of Government on the Capitalist Mode of Production}

As an allegorical story, the author of Kappa employs some features to criticize the Japanese people's life by comparing to the behaviour of Kappa in the Kappaland with the people in Japan in the early $20^{\text {th }}$ century. In this section, the writer of this thesis highlights the allegorical setting, which is role of government in Kappaland in promoting the capitalistic ideas. The writer believes that this depcition is intentionally made by the author as one of the criticism toward human's quality.

Kappaland is a capitalistic state, in which the government supports the capitalist socioeconomic system to grow in their country. Before explaining the role of the government in promoting the capitalistic ideas to the kappa civilians, one has to aware that kappaland is the country ruled by government. Kappa has a developed society in which they choose several people to be the representative in the top of governance.

In the story, the State, as the agent which holds the power in Kappaland is proven to favor the dominant class than the working class. The State has a role in letting the capitalist ideology grow. As the proof, in this novel the State is clearly showing its stance on the side of owner of the means of production in the case of retaining condition of the relation of production in Kappaland. The State does not provide any safety net for the proletariat-the wage earner-if in any case they are fired by the owner of the means of production. In short, the State supports the relation of production in the Kappaland, where the dominant class exploits the working class. These two entities are paying taxes to the government, but preference action is given by the State to the dominant class in the society. In the case of industrial unemployment, the State takes the stance on the capitalists. 
To be clear, the State passes a regulation that legalize the act of slaughtering the unemployed Kappas. The term 'slaughtering' in Kappaland contains a literal meaning. In one of the discussion between Inmate No. 23 and the kappas, Pep the judge, says "what Gael means was that we slaughter any worker who loses his job..." (Akutagawa, 2009: 88). In this story, 'slaughtering' Kappa is not a figurative expression. The expression suggests an action of killing a large number of Kappas in one time for their meat.

This action could happen because of the legalization by the State. Slaughtering Kappas who loses their jobs is an act of double repression. First, the unemployed Kappas has loses their sustainable income. They are no longer able to afford a living, including the shelter, the clothes, and most importantly the food.

The State action to slaughter the working class Kappa who are laid off by the companies is an easy way out. By slaughtering the working class Kappa, the government will not be responsible to take care of their lives when they are no longer have sustainable income. Kappas who are fired by the owner of capital will be soon or later suffers from starvation for they cannot afford food. It is suggested that "by such action, the State takes over and saves a man all the bother of suicide or death by starvation" (Akutagawa, 2009: 84).

The law enacted by the State is a clear statement. It shows that the State of Kappaland is the agent of repression who works for the interest of the dominant class. Althusser argues that the State is a repressive apparatus which caters the interest of the ruling class, the bourgeoisie. The State is controlled by the economically dominant class:

The State is a 'machine' of repression, which enables the ruling classes (in the nineteenth century the bourgeois class and the 'class' of big landowners) to ensure their domination over the working class, thus enabling the former to subject the latter to the process of surplus-value extortion (i.e. to capitalist exploitation) (Althusser, 1971:137)
The repression comes in many ways, including the visible repressive way and the imperceptible way. The means to ensure the dominance of the ruling class is helped by the Repressive State Apparatus and the Ideological State Apparatus. The Repressive State Apparatus, which functions by violence, contains the Government, the Administration, the Army, the Police, the Courts, the Prisons. The act of repression by the Repressive State Apparatuses might take physical or nonphysical forms. The Ideological State Apparatus, is described by Althusser as the system of school, politics, family and communication.

The way Kapanese government passes the law on slaughtering unemployed Kappa as a just action may spread the message to the rest of citizens that it is just and normal to treat the working class as a subordinate civilians. If the workers are no longer productive, they might cause more problems, including the raise on the poverty rate, which force the government to help them by raising the tax or cutting the government expense for other public necessity. That is why the government makes a law to banish the unemployed Kappa from the Kappaland as soon as possible by slaughtering them. In addition, they are able to get the meat of the workers, so the price of the meat decrease.

This working class, in this case, is the victim of the capitalistic way of production. They had sold their labor power, in order to earn money for a living, but they are not treated like humans. Workers tend to be treated as one of the factors of production; not any higher than machines. When they are no longer productive or cannot comply with the target, they are dumped like trash.

The phenomenon of replacing human with machine in a mode of production can be read as a deterioration of humanity. Conditioning human as one of the commodity happens only in a capitalistic mode of production. Human is treated like a commodity, besides raw material, fixed installations (building), and any instruments of production for instance machines to produce goods and services in the capitalistic mode of production. 
When the target of production is raised by the capitalists-which is actually unnecessary-in order to gain more profit, the human power will be automatically taken over by the machine. The machine is known as a tool with nearly zero mistakes. It has a prominent ability to produce more goods and services in no time compared to human. The owner of the means of production will tend to argue that that is the time to lay off workers and run the machines instead. The cost of ensuring human to produce the same amount of energy and labor power to present in the factory in the next days will be much higher than the costs to buy and maintain the machines; as in fact machines could do better than human in terms of quantity.

As Althusser (1971) posits in order to reproduce the labor of power, the firm should give the labor material means to reproduce itself, which is the wage capital. The wage capital is in fact not the result of the worker's work in the factory, but the material means to reproduce the "wherewithal to pay for housing, clothing and in short to enable the wage earner to present himself again at the factory gate the next day".

The act of slaughtering Kappas cannot be related with the literal meaning in the Japanese relation of production. When reading this action we should not take it into account. According to Tambling "reading involves choices, deciding, perhaps unconsciously, what should be taken literally, at face value, and what should be taken allegorically" (Tambling, 2010: 15). One of the possible meanings of this surface story suggests is that capitalistic mode of production in Japan results in industrial unemployment. Akutagawa employs the exaggerative way, which is to make something worse than it really is, to highlight the exploitative system of capitalist production.

Capitalism, by its nature, is exploitative. The owner of the means of production exploits the working class to accumulate wealth. This system enables the concentration of capital and the means of production (factories, business, machinery) at the hand of the relatively small amount of people, the dominant class. Associated with unfair distribution of wealth and power, capitalism also has a tendency toward economic and cultural exploitation.

One of the economic exploitation that capitalism generates is its treatment of labour, which makes labour analogous to all other commodities, namely factories, land, raw materials and machines. Labour power is bought at the minimum price so that the capitalists, the owner of the means of production, able to gain more wealth from the price gap. While the capitalists control all the means of production, the only thing workers can control is their labor power. They are, either with consent or not, exploited by this vicious cycle of selling their labor power at a minimum price and as the return get the wage in order to survive. Workers must allow their labor power to be exploited or face starvation. The exploitation of working class is what Akutagawa criticizes in his allegory of government in Kappaland.

\section{The Role of Capitalists, Media and Ruling Party}

In this section the writer highlights the relation between capitalist, media and ruling party in the capitalistic State. Capitalism as an ideology cannot stand alone to retain its position in the mind of every civilians of a State. The ideology needs Apparatuses of the States to ensure the dominance of the ruling class and the subordination of the working class. In addition, the ideology is used to ensure the relation of production in the capitalistic mode of production, which requires the workers to be willing to stay subjected.

In Kappa, Akutagawa throws a vivid image that in order to prolong its dominance in a State, the capitalists must control some of the key elements in the State, namely media and ruling party. The relation between capitalists, media, and ruling party is powerful to control the mind of citizens. Each of the elements is deemed essential to preserve submissiveness of the working class and control the rest of the State. 
The writer of this thesis found some essential roles of media and political party in Kappaland as it is depicted by Akutagawa in Kappa. The quotation below might well represent how the power of media is held by the capitalists, the upper class with the tendency to control the head of the lower class "But don't run away with the idea," went on Gael, "that this Qui Qui is his own boss. Not a bit of it-there's yet one more person above and beyond him, none other than Gael you see in front of you" (Akuagawa, 2009: 88)

In the quotation above Gael, the director of glass corporation, mentions that he is a person above and beyond Qui Qui, the owner of PouFou paper, one of the prominent paper in Kappaland.

Gael knows that the media essentially function as the means to spread information, as the ground of society for making decisions, and may lead the public opinion. Through its framing and editorial policy media could inject certain ideology and values intended by the ruling ideology.

The capitalists, are by their very nature, always seek for profit and benefit to reach a certain target and to manipulate the government regulation to support their interest. The dominant class will use their power of controlling media because they are not a social institution which do not seek for their own benefit. Moreover, the media has the power to control the people's mind through its selective data and news produced in daily basis.

Gael's control over the PouFou paper is quite surprising for Inmate No. 23 when in fact he knows that this newspaper is the ally of the worker. He feels terrible to imagine that the leader of media, which associates with the working class turns out to be under the capitalist's control. He speaks through his inner voice that "as I watch Gael, I felt not so much hatred of the man himself, as a deep sympathy for the wretched PouFou reporters," (Akutagawa, 2009: 88).

Explicitly Gael reveals that without his help, Qui Qui, the owner of the media as well as its reporters will not survive:
"The PouFou reporters, naturally, are all for the working man, as you'd expect. But, well, you'll agree that they are influenced and controlled by their boss, Qui Qui-and Qui Qui, off course, couldn't survive without support from me." (Akutagawa: 2009: 88)

The quotation above shows that there is a mutual relation between Gael and the owner of the media, Qui Qui. Most of the time, the media face the hardship to retain its position as a company. To maintain its existence, the media can not only rely on the newspaper selling profit, but also from the money generates from the advertisement space and other means of partnership. Dualism as a company and as the communication means makes it hard for the media to stay idealist in terms of serving the news for the humanity and the society's greater good.

Gael, as the owner of capital, benefits from this condition. In return, he hopes that his help to the media will bring more benefit for him. Because capitalists believe that there is no such thing as free lunch. What he gives is not a donation to the media. The benefits that might be gained are first the promotion of the product that his company sells. Every company has to be known by the society thus they need the media to advertise its products and services. Second, from this relation the media will ensure that they will not scrutinize any bad practices of the company. It means they will project the good side of the company. Third, media can be the agent of conditioning the workers for not making any political unrest by normalizing the exploitation they undergo. It is, not to mention, that the media has also planted in the people's mind the idea that the capitalistic way of production is justifiable and necessary to be followed.

In fact, this media can be regarded as what Althusser suggests, the Ideological State Apparatus, which is the apparatus which is working massively and predominantly by ideology. This ISA operates in a subtle way and avoids repression to internalize values and ideologies to the society. The way it goes through somebody's mind is not very 
noticeable so that they cannot see and reject it.

As an institution, the media owned by Qui Qui is not a government's media. Yet, from Althusser's perspective, this private media is still regarded as an Ideological State Apparatus for it serves the same goal as the government's goal, which is to ensure that the domination of the ruling ideas will last long and contribute generously to the reproduction of relations of production which is the capitalists relations of exploitation. The ISA teaches the modesty, resignation, submissiveness to the domination of the owner of capital. Althusser, on this matter, suggests that "it is unimportant whether the institutions in which they are realized are 'public' or 'private'. What matters is how they function" (1971:144).

The other things criticized by Akutagawa in Kappa is Gael's influence to the political party by controlling the head of the political party. Quorax Party, the ruling party in Kappaland at that time, is controlled by the PouFou paper. This PouFou paper is controlled by Gael. In short, the party, including its Quorax Cabinet is also controlled indirectly by this capitalist kappa.

Inmate No. 23 gets the sense that the ruling party, the Quorax Party is not serving the interest of all kappanese, but the dominant class. As a non-Kappa resident, he is told a secret by Gael that Loppe, the head of the party, is controlled by the owner of the PouFou paper. This quotation below shows how this relation works.

"It's Loppe I want to talk about, not his speeches or his lies. Now, Loppe-he's in control of the Quorax Party. But there's someone behind Loppe, and in control of him-and that's Qui Qui, the president of the PouFou newspaper" (Akutagawa, 2009: 87)

Gael's control over PouFou paper and Quorax Party is a significant quality Akutagawa attaches to the allegorical characters. Since, Gael represents the Japanese capitalist, Akutagawa wants to say through his story that this is how the ideology of capitalism works in Japan. The capitalist can retain its position as the dominant class by overpowering the elements of the State.

By strengthening their influence to the political sphere, those capitalists secure their interest as well as discipline the working class by the implementation of social order through education. Keeping the relation of production in the capitalist mode of production, in which the working class is subjected by the owner of the means of production, is the goal of those capitalists.

\section{How the Allegory can be Regarded as a Criticism}

The first problem formulation answered the parallelism between Kappalandsociety with the Japanese. In this sub-chapter, the writer of the thesis attempts to uncover the function of allegory as a means to criticize and how each element of allegory contributes to the critics uttered by Akutagawa to the ruling ideology in Japan. To answer the question of how allegory is employed in criticizing the ruling ideology in Kappaland as well as in Japan, there are some allegorical devices that should be uncovered, namely the allegorical setting, the characters, significant events and some exaggeration used by the author.

As Leyburn (1948) suggests that allegory can function as "a means of making satire direct and immediate". In Kappa, Akutagawa employs the mythological creature to present human weakness, such as human's greed, ignorance, even the inhumane and immoral behavior. The form of Kappa as an allegory of human is a kind of direct criticism, which is used to show the weakness and disgusting side of human.

Akutagawa actually presents a true face of human with a deformed mirror by using Kappa as the character. In his story Kappa might be a reflection of human in many ways, including the evil side in human's personality and traits. The mass slaughter of the unemployed Kappas and cannibalism are the representation of Japanese society, who in daily basis, promotes and involves in the capitalistic mode of production either as the 
part of the dominant class or the working class.

The capitalist mode of production in Japan is suggested by Fujita in Ike (1949) that "as industrialization proceeded, the communal life in Japan tended to disintegrate, and the role of capital in both agriculture and industry became more important. Moreover, 'feudal labor' was converted into 'de facto wage labor'". The livelihood of working class Japan in the industrialization era depends on the wage as the labor. Under the capitalist mode of production the status of most labor in Japan from 'feudal labor' was converted into 'wage labor'. However, the coercive power of the feudals in the feudal mode of production is essentially similar with the coercion in the capitalist system, which is compelling the working class to sell their labour power to the owner of the capital.

One should discover the meaning beneath the story to get into the sense of Akutagawa criticism. As it is suggested by Tambling:

The other meaning of allegory may conceal a secret significance, in that it may persuade readers to probe for another meaning, it may enrich the meaning that has been given, or it may draw attention to a split between the surface meaning and what is underneath (2010: 28).

The surface story of Akutagawa's Kappa is about the institutionalized mass slaughter of unemployed Kappas and how Kappas are allowed to eat the flesh of working class Kappa who are fired and replaced them by the machines. This story should not be read literally. Rather, it should be understood as an allegory. The mass slaughter might suggest a criticism toward the class relation and the nature of capitalism in Japan during Taisho period. By its very nature, capitalism is exploitative. It enables the subjection of the working class by the owner of the means of production. Additionally, the way capitalists generate their profit by extracting working class' surplus value is a form of exploitation.
Mass unemployment in Kappaland that leads to mass slaughter is an exaggeration used by Akutagawa to show that the working class is subjected by the capitalists. In the capitalistic mode of production, the proletariat are compelled to sell their labour power. In fact, the working class in Japan also happened to face the unemployment in the early 20th century, as Kato suggests:

Needless to say, the 1920s were from the beginning characterized by a large amount of unemployment. Little of the enormous profit from the war reached the working class, who first suffered from low wages, then inflation, and then from the threat of unemployment. They thus had little or no hope of escaping misery in crowded urban industrial areas, and some workers protested, petitioned, went on strike, demonstrated in the streets, and often clashes with police. For the first time in modern Japan, labor conflict became a social problem of importance (1998:32).

However, the mass killing and cannibalism do not take place in Japan. This is the form of exaggeration in the allegory to strengthen the idea that capitalism might kill the working class once their labor power is no longer compelling to be used in the process of production. The unemployed working class is unable to afford the living, including the meal and shelter once their source of income is cut off. Moreover, they are the class who is deprived of the means of production, which is hard to get into the process of production, for the only power they have is the power over their labor power.

The ownership of the means of production is centralized to the capitalists. The capitalist are those who are not engaged in the simple manual labor, but specialized privileged work.

In his story Akutagawa also shows how capitalism positions the labor power of the working class as a commodity, the part of the means of production, while the bourgeoisie are benefited from exploiting the working class. He contests the idea of capitalism by creating an allegorical character who is 
attributed with the label of 'capitalist'. The description is shown in Inmate No. 23's comment on Gael's appearance and his nature. Inmate No. 23 says that Gael is "the capitalist to end all capitalist" (Akutagawa, 2009: 81). This capitalist Kappa is used by Akutagawa to show how capitalism works in Kappaland. First, Gael invites the narrator to one of the factories in Kappaland which produces a mass number of books. In the factory, Inmate No. 23 observes the demonstration of how the book production is held and describes it as

In Kappaland, all they do to produce a book is to pour paper, ink and a greylooking powder into a funnel-mouthed machine. The ingredients are fed into the machine and, in barely five seconds, they are ejected as octavos, duodecimos, royal octavos and so on (Akutagawa, 2009)

The production of books in Kappaland is quick and resulted in very plentiful number. However, the critic lays on the substitution of working class Kappas with the highly mechanized tools. This critic is supported by the setting and characters that Akutagawa employs in the allegory. Gael tells Inmate No. 23 that in an average month Kappaland sees the invention of as many as seven or eight hundred new devices of this kind. This shows how in Kappanese "the process of introducing mass production is going ahead at very rapid pace" (Akutagawa, 2009:83). As a result of this mass production, no less than forty or even fifty thousand Kappas lost their jobs.

The second criticism of the capitalist mode of production is targeted to the role of the State and its apparatuses in supporting the exploitation of the working class. The fact that the mass production in Kappaland sacrifices the occupation of thousands of working class Kappas and the cannibalism is issued by the State as the simple escape mechanism shows that the State is ruled by the capitalist ideology. Pep, Kappa Judge, makes it clear that Kappas "have a statute covering the butchery of the worker" (Akutagawa, 2009: 84).

Moreover, Pep emphasizes that the State does the mass killing as humane as possible to be seen as the savior of those unemployed Kappas by saying that "by such action, the state takes over and saves a man all the bother of suicide or death by starvation" (Akutagawa, 2009:84). At this point, Akutagawa aims an attack to criticize the nature of the State as it is suggested by Althusser:

The State is a 'machine' of repression, which enables the ruling classes (in the nineteenth century the bourgeois class and the 'class' of big landowners) to ensure their domination over the working class, thus enabling the former to subject the latter to the process of surplus-value extortion (i.e. to capitalist exploitation) (Althusser, 1971:137).

The reproduction of the relation of production should be ensured by the power of the state. Thus, in this sense, the State and its apparatuses, including the Army, Police, the media and political party are the agent of capitalists to dominate the working class and extort their surplus value.

\section{Conclusion}

Starting with analyzing the parallels between the world of Kappa and the real the world of Japan in the early $20^{\text {th }}$ century, this thesis aims to prove that Kappa is a social and political representation of the world in which the author, Akutagawa lived. The elements that are scrutinized in the first problem formulation is the allegorical characters, allegorical setting, and allegorical events. Those elements signify the life-likeness of the real Japan.

The rapid industrialization, the war between neighboring countries, the vicious cycle of capitalism and the restriction of establishing union labor as well as halting the strikes aims to accommodate the interest of the working class are highlighted as the surface and beneath of the story. In getting this clear picture of meaning, the writer of this thesis employed the theory of allegory.

The result of the first problem formulation leads to the second problem formulation, which is how this allegory used 
to criticize the ideology of capitalism in Japan. The allegorical characters, the setting, and significant events are employed by the author to direct the reader to certain meaning in the story beneath. These elements of allegory are employed to criticize human's lacks and shortcomings, that sometimes they are not aware of.

Kappa, the mythological creature, is deliberately chosen by the author to exploit certain values. By exaggerating its tendency and actions Akutagawa presents a deformed mirror to human. It is to signify that humans are as disgusting as Kappa. Inmate No. 23 becomes the representation of innocent but critical man, the idealization of human in general. This specially protected person in Kappaland, is unaware of its shortcomings and tend to criticize the practice of Kappa. The characters of Kappa are attributed to certain values and characteristics. Gael is attributed with the opportunist, profitoriented, and capitalist nature. Mag is regarded as a Kappa with the critical thinking and depth analysis, to answer the difference between Kappaland and the human world. In addition, Lap is the Kappa students who guided and accompanied Inmate No. 23 to know the Kappaland better.

In addition, the second problem formulation contains the question of how this allegorical Kappaland criticizes the practices in the human world. The theory of the ideology contributes in explaining how the ideology of capitalism is internalized to ensure the existence of the State with the capitalist mode of production.

Using the theory formulated by the French Marxist philosopher, Louis Althusser, the writer of this thesis found that the Ideological State Apparatus (ISA) works in many channels and ways. It goes along with the system of politics and through the media. Those two essential elements are, in fact, controlled by the Kappa capitalist, Gael. What this fact signifies is that in the real human world, there are apparatuses, the Ideological State Apparatuses, which are hand in hand, reproducing the means of production, and to ensure the relation of production i.e. domination and exploitation by the ruling class to the working class continues.

At the end of analysis, it is proved that allegory in Akutagawa'sKappa is a device to criticize the life of Japanese society in the early $20^{\text {th }}$ century. First, Akutagawa employs the Kappas as the reflection of human in Japan whose mode of production is a capitalistic way. It tends to subject the working class Japanese similar to what Kappanese do to their working class. Second, through the exaggeration, Akutagawa shows that the ideology of capitalism is in its very nature exploitative.

\section{References}

Abrams, M.H. A Glossary of Literary Terms. Ninth Edition. Boston: Wadsworth Cengage Learning, 2009.

Althusser, Louis. Lenin and Philosphy and other Essays. New York: Mothly Review Press, 1971.

Akutagawa, Ryunosuke. Kappa. London: Peter Owen Publishers, 2009. Barefelt, Gunnar. "On Symbol and Allegory". The Journal of Aesthetics and Art Criticism. Vol 28, No. 2 (1969): pp. 201-212. JSTOR (www.jstor.org/stable/428569)

February 11, 2016.

Bennett, Andrew and Nicholas Royle. An Introduction to Literature, Criticism and Theory. Harlow: Pearson Education Limited, 2004.

Boudon, Raymond. The Analysis of Ideology. Chicago: The University of Chicago Press, 1989.

Boyd, James Robert. Elements of Rhetoric and Literary Criticism, with Copious Practical Exercises and Examples, for the Use of Common Schools and Academies. Eight Edition. New York: Harper \& Brothers Publisher, 1860. 
Bressler, Charles E., Literary Criticism: An Introduction to Theory and Practice. Englewood Cliffs, NJ: Prentice Hall, 1999.

Brooker, Peter. A Glossary of Cultural Theory. New York: Bloomsbury, 2002. Copeland, Rita and Peter T. Struck. The Cambridge Companion to Allegory. New York: Cambridge University Press, 2010.

Cowan, Bainard. "Walter Benjamin"s Theory of Allegory". New German Critique. No. 22 Special Issue on Modernism (1981): pp. 109-122. (www.jstor.org/stable/487866) February 11, 2016.

Eagleton, Terry. Marxism and Literary Criticism. London: Routledge Classics, 2002.

Fletcher, Angus. Allegory: The Theory of a Symbolic Mode. New York: Cornell University Press, 1964.

Forster, E.M. Aspects of the Novel. New York: A Harvest Book, 1985.

Fulcher, James. Capitalism: A Very Short Introduction. New York: Oxford University Press, 2004.

Giddens, Anthony. Capitalism and Modern Social Theory: An Analysis of the Writings of Marx, Durkheim and Max Weber. Cambridge: Cambridge University Press, 1971.

Holman, C. Hugh. A Handbook to Literature. Indianapolis: Bobbs-Merrill Educational Publishing Company, Inc., 1960.

Howell, David L. Capitalism From Within: Economy, Society, and the State in a Japanese Fishery. Berkeley: University of California Press, 1995.

Ike, Nobutaka. "The Development of Capitalism in Japan". Pacific Affairs. Vol. 22. No. 2 (1949): pp. 185-190. JSTOR. (www.jstor.org/stable/2751596) September 23, 2015.
Kato, Shūichi. "Taisho Democracy as the PreStage for Japanese Militarism". Showa Japan: 1926-1941. Large, Stephen S. New York: Routledge, 1998.

Koon-ki, Ho. "Kappa as a Dystopia: A Study of Akutagawa"s Anti-utopian Thought". NOAG . No. 153. (1993): pp.45-62

Leyburn, Ellen Douglass. "Notes on Satire and Allegory". The Journal of Aesthetics and Art Criticism, Vol. 6, No. 4 (Jun., 1948): pp. 323-331. JSTOR (www.jstor.org /stable/426959) February 4, 2016.

Lois, Tyson. Critical Theory Today: A Userfriendly Guide. New York: Routledge, 2006.

Mardiana, Theresia Vemi. "Social Criticism toward Japanese Society in 1920s as Revealed through the Life of Imaginary Characters in Ryunosuke Akutagawa"s Kappa". Undergraduate Thesis. Yogyakarta: Sanata Dharma University, 2008.

Marshall, Byron K. Capitalism and Nationalism in Prewar Japan: The Ideology of the Business Elite, 1868-1941. California: Stanford University Press, 1967.

Marx, Karl. Capital: A Critique of Political Economy. Volume Two. London: Penguin Classics, 1993.

Morishima, Michio. "A Historial Transformation from Feudalism to "Capitalism"”. Discussion Paper. No. JS/86/138. (1986): pp. 1-60.

Peace, David. Last Words. The Guardian Book Review. September 8, 2007. https://www.theguardian.com/books/2 007/sep/08/featuresreviews.guardianre view13. February 15, 2016.

Rubin, Jay. From "Wholesomeness to Decadence: The Censorship of Literature under the Allied Occupation". The Journal of Japanese Studies, Vol 11, No. 1 (Winter, 1985) pp.71-103. (www.jstor.org /stable/132230) June 30, 2016. 
Shigeto, Tsuru. "The Economics of the Meiji Restoration". Japan's Emergence as a Modern State: Political and Economic Problems of the Meiji Period. Norman, Herbert E. Vancouver: UBC Press, 2000.

Spisso, W. "Ideology and Practice: The Material Social Production of Human Experience". On Politics (2006): pp. 83 93.

Tambling, Jeremy. Allegory: The New Critical Idiom. New York: Routledge, 2010.

Tsuruta, Kinya. Review. Monumenta Nipponica, Vol 27, No. 1. Tokyo: Sophia University, 1972.

---------------. AkutagawaRyunosuke: His Concept of Life and Art.

Dissertation. Seattle: University of Washington, 1967.

Widiharyanto, Norbertus I NyomanEdy. "The Functions of Allegory in Hemingway"sThe Old Man and The Sea". Undergraduate Thesis. Yogyakarta: Sanata Dharma University, 2001.

Yu, Beongcheon. Akutagawa: An Introduction. Detroit: Wayne State University Press, 1972. 